\title{
Relationship between P-Wave Dispersion and Effective Hemodialysis in Chronic Hemodialysis Patients
}

\author{
Namik Ozmen $^{\mathrm{a}}$ Beker Sitki Cebecia ${ }^{\mathrm{a}}$ Ejder Kardesoglu ${ }^{\mathrm{a}}$ Enes Murat Atasoyu ${ }^{\mathrm{b}}$ \\ Suat Unver ${ }^{b}$ Turgay Celik $^{c}$ Mustafa Aparci ${ }^{\mathrm{a}}$ Mehmet Dincturk ${ }^{\mathrm{a}}$ \\ Departments of a Cardiology and bephrology, Gulhane Military Training Hospital, Haydarpasa Teaching Hospital, \\ Istanbul, and 'Department of Cardiology, Gulhane Military Medical Faculty, Ankara, Turkey
}

\section{Key Words}

Hemodialysis $\cdot$ Dry body weight $\cdot$ P-wave dispersion

\begin{abstract}
Objective: To investigate whether or not P-wave dispersion (PWD) can be used as a good indicator of effective hemodialysis. Subjects and Methods: The study included 35 patients (20 males, 15 females, mean age $61 \pm 10$ years) who regularly received hemodialysis treatment for chronic renal failure. Following hemodialysis, the patients whose hemodynamic parameters were preserved and who reached dry body weight were included. Twelve-lead resting electrocardiogram (ECG) at a speed of $25-50 \mathrm{~mm} / \mathrm{s}$, the value of total body fluid (TBF) and bioelectric impedance using bipedal bioelectric impedance equipment were obtained before and immediately after hemodialysis. Blood samples were also taken for the assessment of blood electrolytes, urea and creatinine. PWD was defined as the difference between the maximum and minimum P-wave duration calculated on a standard 12-lead ECG before and after dialysis. Results: The following parameters were obtained before and after hemodialysis: blood pressure $132 \pm 21$ vs. $130 \pm 10 \mathrm{~mm} \mathrm{Hg} \mathrm{(p>}$ $0.05)$, TBF $33.9 \pm 6$ vs. $32 \pm 5.6$ liters $(p=0.001)$, impedance
\end{abstract}

\section{KARGER}

Fax +41613061234

E-Mail karger@karger.ch

www.karger.com
(C) 2007 S. Karger AG, Basel

1011-7571/07/0162-0147\$23.50/0

Accessible online at:

www.karger.com/mpp
$499 \pm 110$ vs. $596 \pm 136 \Omega(p=0.001), P-\max 103.1 \pm 8.9$ vs. $106.3 \pm 12.7 \mathrm{~ms}(\mathrm{p}>0.05), \mathrm{P}-\mathrm{min} 70.2 \pm 11 \mathrm{vs} .72 .5 \pm 7.9 \mathrm{~ms}$ $(p>0.05)$, PWD $32.2 \pm 11.9$ vs. $33.8 \pm 13.4 \mathrm{~ms}(p>0.05)$. Although statistically significant decreases were observed in urea and creatinine levels after hemodialysis, no such changes were observed in blood electrolytes. Conclusion: The P-max and PWD did not change significantly after hemodialysis, hence these two parameters can be used as an indicator of effective hemodialysis.

Copyright $\odot 2007$ S. Karger AG, Basel

\section{Introduction}

Numerous studies have demonstrated a correlation between the delivered dose of hemodialysis and patient mortality and morbidity. Evidence demonstrates that mortality among end-stage renal disease (ESRD) patients is lower when an appropriate minimum dose of hemodialysis is provided. To ensure that ESRD patients treated with chronic hemodialysis receive adequate treatments, the delivered dose of hemodialysis needs to be measured. Clinical signs and symptoms alone are not reliable indicators of dialysis adequacy [1-5]. 
The delivered dose of hemodialysis in adult patients should be measured using formal urea kinetic modeling or urea reduction ratio (URR). The NKF K/DOQI guidelines for hemodialysis adequacy acknowledge the ease of calculation and resultant popularity of the URR [6], which has been shown to be a statistically significant predictor of mortality for ESRD patients $[1,5]$. The adequate hemodialysis dose should be equivalent to an average URR of $65 \%$ [6].

Cardiovascular disease is the major cause of morbidity and mortality in patients with ESRD [7, 8]. Data suggest that uremic factors or factors related to renal replacement therapy or dialysis may be implicated in the pathogenesis of heart disease in patients treated by dialysis, because cardiovascular survival improves after transplantation even in high-risk patients $[9,10]$. Patients with ESRD have a unique excess of sudden death from cardiac arrest, which includes a separate category for arrhythmia (13\% of cardiac deaths) $[7,8]$. Indeed, it has been shown that the prevalence of atrial fibrillation is $13 \%$ in hemodialysis patients [11]. Furthermore, increased P-wave dispersion (PWD) may account for the increased prevalence of atrial fibrillation [12]. In this study, we aimed to determine the correlation between hemodialysis adequacy and PWP in chronic hemodialysis patients.

\section{Materials and Methods}

The study included 35 patients ( 20 males, 15 females, age $61 \pm$ 10 years), who regularly received hemodialysis treatment for at least 6 months and were in a stable condition. Patients had dry weight clinically (that is, normotensive, edema-free and cardiothoraxic index $<0.5$ ) and no history of atrial fibrillation. Following parameters were obtained before and immediately after hemodialysis: body weight, blood pressure, total body fluid (TBF) and bioelectric impedance (BEI) measured with bipedal bioelectric impedance analyzer device (Tanita-450, Japan), serum electrolyte (sodium, potassium, calcium, phosphate), blood urea nitrogen (BUN), and creatinine. Data were analyzed for patients with significant change in pre- and posthemodialysis TBF and BEI and without compromised hemodynamics.

Following an approximately 5-min resting interval, 12-lead resting surface ECGs were obtained (HP, M1700A, China) at 25 and $50 \mathrm{~mm} / \mathrm{s}$ paper speed. In each derivation, the time period between start and end of the $\mathrm{P}$ wave was determined by using a caliper. The longest $\mathrm{P}$-wave duration was accepted as $\mathrm{P}$ maximum $(\mathrm{P}-\max )$ and the shortest $\mathrm{P}$ wave as $\mathrm{P}$ minimum $(\mathrm{P}-\mathrm{min})$ and the PWD value was the difference between $\mathrm{P}$-max and $\mathrm{P}$-min. In order to avoid interobserver changes, the measurements were completed by the same observer who was blinded to the time of ECG. Pre- and posthemodialysis $\mathrm{P}-\mathrm{max}, \mathrm{P}-\mathrm{min}$ and $\mathrm{PWD}$ values were compared.
Before hemodialysis, left atrial diameter, left ventricular functions and valve structures were evaluated in standard transthoracic echocardiographic examination using an echocardiography machine with $2.5-\mathrm{MHz}$ transducer (GE Vingmed System FiVe, Holten, Norway) according to the recommendations of the American Society of Echocardiography. Using a bipedal BEI analyzer device, TBF (liters) and BEI $(\Omega)$ values were digitally measured by fastening bipedal BEI analyzer pedals to both ankles.

Hemodialysis sessions with F5 and F6 HPS polysulfone (Fresenius Medical Care AG, Bad Hamburg, Germany) were repeated 3 times a week for $4 \mathrm{~h}$ as a standard procedure (40008-B, Fresenius Medical Care). Bicarbonate dialysate fluids contained $140 \mathrm{mmol} / \mathrm{l}$ sodium, $2.0 \mathrm{mmol} / \mathrm{l}$ potassium, $1.5 \mathrm{mmol} / \mathrm{l}$ calcium and $1.0 \mathrm{mmol} / \mathrm{l}$ magnesium. During hemodialysis no drugs were administered, except isotonic $\mathrm{NaCl}$ and heparin. The blood samples were taken according to NKF K/DOQI guidelines [6] for the measurement of URR, and also UUR was calculated according to the formula UUR $=100 \times(1-\mathrm{Ct} / \mathrm{Co})(\mathrm{Ct}=$ postdialysis $\mathrm{BUN}$, $\mathrm{Co}=$ predialysis $\mathrm{BUN})[1]$.

\section{Statistical Analysis}

Statistical analysis was performed using a paired Student's $t$ test for continuous variables with the Statistical Package for Windows version (SSPS 11, Chicago, Ill., USA). A p value $<0.05$ was considered statistically significant. All data were expressed as mean $\pm S D$.

\section{Results}

The underlying causes of chronic renal failure were chronic glomerulonephritis $(\mathrm{n}=15)$, hypertension ( $\mathrm{n}=$ $12)$, and chronic tubulointerstitial nephropathy $(\mathrm{n}=8)$. Mean duration of hemodialysis was $3.2 \pm 0.5$ years, mean left ventricular ejection fraction $60 \pm 2 \%$ and mean left atrial diameter $44 \pm 3.3 \mathrm{~mm}$. TBF level decreased from $33.9 \pm 5.9$ to $32 \pm 5.6$ liters $(\mathrm{p}=0.001)$, BEI level decreased from $596 \pm 136$ to $499 \pm 110 \Omega(\mathrm{p}=0.001)$ and there was no significant change in blood pressure levels (predialytic $132 \pm 21$ vs. postdialytic $132 \pm 21 \mathrm{~mm}$ $\mathrm{Hg}$ ).

After hemodialysis, P-max duration extended from $103.1 \pm 8.9$ to $106.3 \pm 12.7 \mathrm{~ms}(\mathrm{p}=0.68), \mathrm{P}-\mathrm{min}$ from $70.2 \pm 11$ to $72.5 \pm 7.9 \mathrm{~ms}(\mathrm{p}=0.78)$ and PWD from $32.2 \pm 11.9$ to $33.8 \pm 13.4 \mathrm{~ms}(\mathrm{p}>0.88)$. The differences in P-max, P-min and PWD levels between pre- and postdialysis measurements were not always statistically significant ( $\mathrm{p}=0.68, \mathrm{p}=0.78$ and $\mathrm{p}=0.88$, respectively).

Average levels of serum potassium, serum phosphate and serum sodium decreased from $5.2 \pm 0.8$ to $4.7 \pm$ $0.7 \mathrm{mmol} / \mathrm{l}, 2.1 \pm 0.1$ to $1.8 \pm 0.9 \mathrm{mmol} / \mathrm{l}$ and $135 \pm 3.1$ to $133 \pm 3.9 \mathrm{mmol} / \mathrm{l}$, respectively, while serum free calcium concentration level increased from $2.2 \pm 0.1$ to 2.5 $\pm 0.1 \mathrm{mmol} / \mathrm{l}$. The difference was not statistically sig- 
Table 1. Pre- and posthemodialysis data

\begin{tabular}{lccc}
\hline & $\begin{array}{l}\text { Predialysis } \\
(\mathrm{n}=33)\end{array}$ & $\begin{array}{l}\text { Postdialysis } \\
(\mathrm{n}=33)\end{array}$ & $\mathrm{p}$ value \\
\hline BUN, mmol/l & $30.1 \pm 3.1$ & $17.2 \pm 2.2$ & 0.001 \\
Creatinine, $\mu \mathrm{mol} / \mathrm{l}$ & $870 \pm 120$ & $380 \pm 80$ & 0.001 \\
Sodium, $\mathrm{mmol} / \mathrm{l}$ & $135 \pm 3.1$ & $133 \pm 3.9$ & 0.69 \\
Potassium, mmol/l & $5.2 \pm 0.8$ & $4.7 \pm 0.7$ & 0.50 \\
Calcium, mmol/l & $2.2 \pm 0.01$ & $2.5 \pm 0.1$ & 0.89 \\
Phosphate, $\mathrm{mmol} / \mathrm{l}$ & $2.1 \pm 0.1$ & $1.8 \pm 0.9$ & 0.08 \\
\hline
\end{tabular}

nificant. BUN and creatinine decreased significantly after dialysis $(30.1 \pm 3.1$ vs. $17.2 \pm 2.2 \mathrm{mmol} / \mathrm{l}, \mathrm{p}<0.001$, and $870 \pm 120$ vs. $380 \pm 80 \mathrm{mmol} / \mathrm{l}, \mathrm{p}<0.001$, respectively, table 1).

\section{Discussion}

In this study, hemodialysis patients with a significant TBF reduction after hemodialysis had a statistically nonsignificant increase in P-max, P-min and PWD values. However, when considered together with significant reduction in weight, TBF and BEI, the nonsignificant change in PWD value could be an indicator of effective hemodialysis in ESRD patients.

Effective hemodialysis is an important issue in chronically hemodialyzed patients. Insufficient hemodialysis causes volume overload and inability to remove toxic substances from the body while excessive hemodialysis results in dehydration and electrolyte imbalance. Although there is no gold standard for measuring effective hemodialysis, dry body weight has been recognized as the marker of adequate fluid removal from the patient on hemodialysis.

Because the conduction velocity of depolarization in the atrial and interatrial tissue can be heterogeneous, $\mathrm{P}$ wave duration can be expected to be prolonged and its dispersion from surface ECG increased. The underlying mechanism may be due to an increase in the diameter of the atrial wall, and volume and pressure overload $[13,14]$. Additionally, increased sympathetic activation and electrolyte imbalance may contribute to the inhomogeneous propagation of atrial depolarization [15].

Our results differ from those of previous studies [16, 17] where increased PWD values were observed in hemodialysis patients. The differences could be due to the fact that effectiveness of hemodialysis was not assessed in those studies. Distension of the atria and electrolyte imbalance such as hypopotassemia, hyponatremia due to insufficient hemodialysis can cause an increase in PWD. Excess fluid removal may result in electrolyte imbalance and an increase in PWD. In previous studies [17, 18], a negative correlation was reported between PWD and serum potassium and phosphate levels after hemodialysis. In our study, statistically significant changes in serum potassium, phosphate, sodium and calcium levels after hemodialysis were not observed.

Effective hemodialysis was associated with no change in the level of PWD, thereby indicating that a simple parameter obtained from surface ECG is an indicator of effective hemodialysis in our study. On the other hand, an increased PWD after hemodialysis may represent ineffective hemodialysis and a risk factor for atrial fibrillation.

\section{Study Limitation}

The number of patients included in the study population was relatively limited. ECGs were obtained immediately after hemodialysis; any changes in ECG occurring later, however, were not monitored. Unfortunately we could not perform Holter monitoring of our study patients. A control group including patients with ineffective hemodialysis should have been added to our study to make our results more clear. Nevertheless, all patients had effective hemodialysis, which needs to be confirmed in further studies overcoming these limitations.

\section{Conclusion}

In hemodialysis patients, absence of an increase in PWD can be used as an effective hemodialysis indicator after dialysis. Also, occurrence of atrial fibrillation impairing hemodynamic parameters in hemodialysis patients can be avoided with effective hemodialysis. 


\section{References}

$>1$ Owen WF, Lew NL, Liu Y, Lowrie EG, Lazarus JM: The urea reduction ratio and serum albumin concentration as predictors of mortality in patients undergoing hemodialysis. N Engl J Med 1993;329:1001-1006.

$\checkmark 2$ Collins AJ, Ma JZ, Umen A, Keshaviah P: Urea index and other predictors of hemodialysis patient survival. Am J Kidney Dis 1994;23:272-282.

$>3$ Hakim RM, Breyer J, Ismail N, Schulman G: Effects of dose of dialysis on morbidity and mortality. Am J Kidney Dis 1994;23:661669.

4 Lowrie EG: Chronic dialysis treatment: clinical outcome and related processes of care. Am J Kidney Dis 1994;24:255-266.

$>5$ Held PJ, Port FK, Wolfe RA, Stannard DC, Carroll CE, Daugirdas JT, Greer JW, Hakim RM: The dose of hemodialysis and patient mortality. Kidney Int 1996;50:550-556.

6 NKF-K/DOQI clinical practice guidelines for hemodialysis adequacy: update 2000. Am J Kidney Dis 2001;37(suppl 1):S7-S64.

$>7$ Sarnak MJ, Levey AS: Epidemiology of cardiac disease in dialysis patients: uremia-related risk factors. Semin Dial 1999;12:69-76.
8 US Renal Data System: URSDS 2002 Annual Data Report. Bethesda, National Institutes of Health, National Institute of Diabetes and Digestive Diseases, 2002.

$\checkmark 9$ Wolfe RA, Ashby VB, Milford EL, Ojo AO, Ettenger RE, Agodoa LY, Held PJ, Port FK: Comparison of mortality in all patients on dialysis, patients on dialysis awaiting trans plantation, and recipients of a first cadaveric transplant. N Engl J Med 1999;341:17251730.

10 Bonal J, Cleries M, Vela E: Transplantation versus haemodialysis in elderly patients. Renal Registry Committee. Nephrol Dial Transplant 1997;12:261-264.

11 Varquez E, Sanchez-Perales C, Borrego F, et al: Influence of atrial fibrillation on morbidity-mortality of patients on hemodialysis. Am Heart J 2000;140:886-890.

12 Dilaveris PE, Andrikopoulos GK, Metaxas $G$, et al: Effects of ischemia on P wave dispersion and maximum $\mathrm{P}$ wave duration during spontaneous anginal episodes. Pacing Clin Electrophysiol 1999;22:1640-1647.

13 Dittrich HC, Pearce LA, Asinger RW, et al: Left atrial diameter in nonvalvular atrial fibrillation: an echocardiographic study. Am Heart J 1999;137:494-499.
14 Spach MS, Dolber PC: Relation extracellular potentials and their derivatives to anisotropic propagation at a microscopic level in human cardiac muscle: evidence for electrical uncoupling of side-to-side fiber connections with increased age. Circ Res 1986;58:356371.

15 Allessie MA, Bonke FIM, Scopman FJG: Circus movement in rabbit atrial muscle as a mechanism of tachycardia: the role of nonuniform recovery of excitability in occurrence of unidirectional block as studied with multiple microelectrodes. Circ Res 1976;39: 168-177.

- 16 Tezcan UK, Amasyali B, Can I, et al: Increased $\mathrm{P}$ wave dispersion and maximum $\mathrm{P}$ wave duration after hemodialysis. Ann Noninvasive Electrocardiol 2004;9:34-38.

-17 Szabo Z, Kakuk G, Fulop T, et al: Effects of haemodialysis on maximum $\mathrm{P}$ wave duration and $\mathrm{P}$ wave dispersion. Nephrol Dial Transplant 2002;17:1634-1638.

18 Vazquez E, Sanchez-Perales C, Lozano C, et al: Comparison of prognostic value of atrial fibrillation versus sinus rhythm in patients long-term hemodialysis. Am J Cardiol 2003; 92:868-871. 